N.W. monsoon came from points of E., and not from W., as might have been anticipated.

In this journey I found the clouds at the Polar side of the S.E. Trade coming constantly from a point either side of the surface-wind, that is, from S.S.E. to E.S.E. When well in the Trade, the middle clouds always came from some point more east than the surface-wind, or in accordance with the usual circulation of the southern hemisphere. No high cirrus was ever observed.

We found no doldrum, but ran straight from the Trade, under a bank of cloud, into the N.W. monsoon, in about $12^{\circ} \mathrm{S}$. latitude. In that monsoon the low and middle clouds always came a little more from the N. than the surface N.W. wind, or in the manner of the upper winds of the northern hemisphere. All the high cirri moved from E. or N.E., except on one occasion, when they came from S.

The N.E. monsoon which we picked up on the equator was so clear that I only obtained one observation of cirrus which came from N.E. when the surface-wind was N.N.E. The lower layers of cloud usually drove from the same direction as the surface-wind, though on one or two occasions they came from a point more $\mathrm{N}$. than the surface.

The above results entirely confirm the observations described in my previous letter of a deep S.E. Trade and of an easterly current over the N.W. monsoon.

Colombo, February 15

\section{Glacier Bay in Alaska}

I THANK your correspondent, Mr. Chauncey Thomas, for pointing out my error in describing Glacier Bay as opening into Chilcoot Inlet, and for more exactly indicating its position. When I visited this region I was provided only with a small and inaccurate pocket-map, in which I found it difficult even to trace the course of the steamer, and I was under the impression that the whole of the fiord northward from Chatham Strait was known as Chilcoot Inlet, though my statement would still not be quite correct.

It may be well to add that my object in arranging my rough field-notes for publication was not to describe the glacier as a whole, but to draw attention to some uncompleted observation: of special geological interest which it seemed to me ought to be made known as indications for future explorers; and it should be borne in mind that my estimates of heights and distances were only estimates based on opinion, and not on any system of actual measurement. The very limited time at my disposal, and my desire to get over as much ground as possible in that time, precluded the use of more satisfactory methods.

Bridlington Quay, March I3

G. W. LAMPi,ugh

A Correction, and the Distribution of Appendicularia

(I) THE specimen which I referred to in NATURE (Jan. 7, p. 221) as being probably a new species of Chatoderma, has turned out on a more detailed examination not to be Chætoderma at all. Therefore I must withdraw the statement that that genus has been found in British seas.

(2) Can any of your readers who have been using the tow-net round our coasts give me information in regard to the occurrence of the Appendiculariidæ? Forbes and McAndrew found Appendicularia off the north coast of Scotland in I845. Allman found it in the Firth of Forth in 1858, and Sanders at Torquay, 1873 ; and it has been taken by Huxley on the English coast. It was seen in quantity by Sorby off the south coast of England a couple of summers ago, and I obtained it in Lamlash Bay in 1880 and 1884 , in Loch Fyne in 1883 , and off the Mann coast in 1885. Apparently it is much commoner and more generally distributed than is usually supposed. I would be glad to hear of any additional records of the occurrence of the Appendiculariidæ in our seas.

University College, Liverpool

\section{Morley's "Organic Chemistry"-Correction}

IN my notice of Dr. Morley's "Organic Chemistry" in this week's NATURE, the reference to “Ladenburg's synthetic optically-inactive coniine ( $\alpha$-isopropylpiperidine)" (p. 436) contains an inaccuracy. Instead of "conine" it should read "coniinebase."

Normal School of Science, March I I

\section{"Peculiar Ice-Forms"}

In Nature, vol. xxxi. p. 5, you allowed me to describe, under this heading, a curious and beautiful form of fibrous ice met with near Chamonix, which I, and other of your correspondents who discussed the matter, thought to be very unusual, though later communications seemed to show that it is commoner than we had supposed.

It may be interesting to note that a day or two ago I came upon the same form of ice in considerable quantity in a very unexpected locality, viz. on the path leading from Gerozano to Lake Nemi, in the Alban Hills. Attention was drawn to the circumstance by the crackling of the ice under foot, otherwise there was no visible indication of its presence except that, where it existed, the path was slightly damp (which was not the case on other parts of it), the dampness being evidently due to the partial melting of the upper stratum of the ice, which was everywhere covered with a layer of earth. The ice was almost exactly similar to that found at Chamonix, but only an inch and a half to two inches deep, and in three layers, easily detached from one another, and evidently the result of successive frosts.

We afterwards found that a bank beside the road between Albano and Frascati was covered with the same formation for several hundred yards; but it would certainly have escaped detection, being everywhere covered with earth, if our previous discovery had not led us to recognise it. This proves that it may often exist unnoticed.

The conditions were precisely similar to those under which this particular form of ice has been observed before-viz. a northerly aspect-a very porous soil (in this case volcanic), bright, sunny days, and clear nights with a low temperature.

Rome, March 12

B. WOODD SMITH

\section{REMARKABLE DISCOVERY OF RARE METALS IN DILUVIAL CLAYS ${ }^{1}$}

DR. STROHECKER, of Frankfort, has carefully examined and analysed the clay which is found in the neighbourhood of Hainstadt, near Seeligenstadt, and he has made the remarkable discovery that this clay, which has been largely used for building purposes, contains considerable quantities of some of the rare metals, and more especially cerium. The beds are extensive, and consist of layers differing considerably in appearance and composition.

The composition of picked samples of the two upper layers is as follows:-

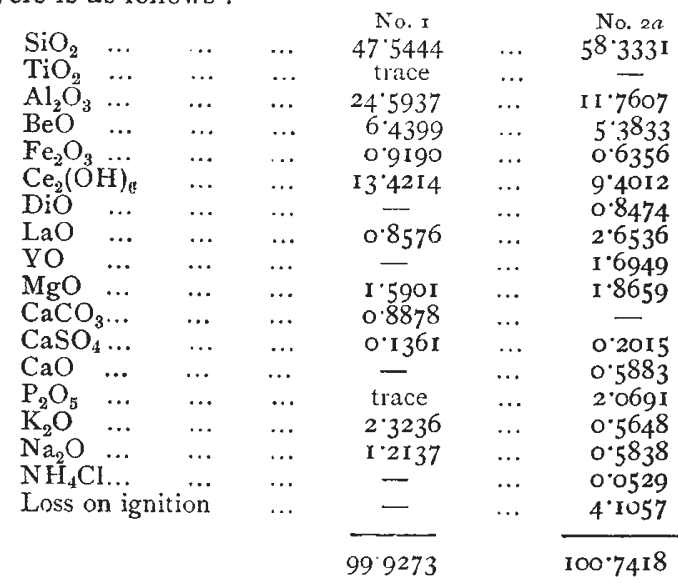

The cerium and yttrium oxides appear to be derived from orthite, which is known to occur in the syenite at Weinheim. The upper layer (No. I) of the clay varies in colour from a bright flesh-colour to a dark cinnamonbrown, indicating that the cerium hydroxide, which is the colouring substance, varies in amount at different points. The bricks made from this clay vary in colour according to the temperature at which they are burnt, the lightlyburnt bricks having an orange-yellow colour, whilst those I Foumal f. prakt. Chenie, $1886, \mathrm{pp} . \mathrm{I}^{2} 2$ and 260 . 
burnt at a white heat are leather-coloured, and have a silver-gray appearance.

The second layer (No.2) is divided into two varieties, $a$ and $b$, the former of which is black from the presence of lignite, and yields lemon-yellow bricks; this colour is due to the conversion of the cerium oxide $\mathrm{Ce}_{2} \mathrm{O}_{3}$ into the lower oxide $\mathrm{Cs}_{3} \mathrm{O}_{4}$ by the action of the carbon which is present. The $b$ variety is blackish-gray, and yields orangered to orange-yellow bricks.

The third layer contains less cerium than the other two, and the bricks made from it are of a fainter orange colour.

The amount of glucina present is very characteristic of the Hainstadt clay. Ammonium chloride, which occurs only in traces in some portions of the clay, exists in quantity in others; and in one piece which crumbled to pieces a crystal of sal-ammonia was found measuring about 2 centimetres in length and $I^{\circ} 5$ centimetres in thickness.

It will be seen from the above that the oxides of cerium which were hitherto of only theoretical interest, are now of technical importance. They have long served as colouring substances in building materials without the fact having been known, and from the large amount present in the Hainstadt clay there are prospects of their being brought into use as paints.

The variation in the colour of the bricks, already mentioned as being produced according to the degree of heat to which they are submitted in the process of burning, does not appear to be due to any action of the silicate on the ceric oxide, as the latter substance can itself be made to assume either colour by igniting it at a suitable temperature. The small amount of iron present in the clay is found to have no influence on the colour of the bricks, which however is affected by the admixture of larger quantities of iron. Dr. Strohecker mentions a number of streets in Frankfort in which houses constructed of the different sorts of cerium bricks are to be seen; the leather-coloured bricks occur in Palmstrasse, Bergerstrasse, Schleidenstrasse, Schillerplatz, Goetheplatz, \&c. ; the orange-red bricks at the police-station, the law-courts, and in the walls of the zoological garden, \&c., and the lemon-yellow bricks at a villa near the west station at Hanau, and at a house in the Verlängerte Zeil at Frankfort. The houses of the peasants near Hainstadt are built of lightly-burnt bright flesh-coloured and yellow bricks.

The somewhat remarkable fact that chemists have so long failed to recognise anything other than ferric oxide as the cause of the colours in these bricks may probably be explained by the large number of shades of colour produced by iron in its various stages of oxidation, by the presence of manganese, and by the employment of mixed clays containing the oxides of both cerium and iron.

\section{HARVARD COLLEGE MUSEUM REPORT}

$\mathrm{P}$

ROF. AGASSIZ' Report, dated October I885, has 1 just reached us, and, as usual, it presents several topics of interest. Since the first section of the Museum was inaugurated in November 1860 , the establishment has passed through many changes, and from being, at its origin, a State institution, it has gradually assumed that of an independent department of the Harvard College. While it has thus lost the immediate support of the State, it has gained the good will and interest of the students of the College, the class upon whom it must in a very great measure depend not only for its maintenance, but for its being a source of intellectual and scientific good.

During the first decade of its existence the resources of the Museum were spent in forming collections which, in some branches of science, have made it a great scientific centre. During this period of ingathering the teach- ing powers of the place were interfered with. Now this period has so far passed that the resources of the place will be chiefly expended on its teaching, its original investigations, and its publications.

The foundation of this Museum dates from the publication of the "Origin of Species." The powerful movement effected by this work on the scientific thought of the age has not failed in modifying the problems which this institution was intended by its original founder to illustrate and to solve; and rightly does the son write that, if the synoptic, systematic, faunal, or palæontological collections should cease to bear the interpretation given to them by his father (the founder), their interest and importance for the advocates of the new biology would not be one whit lessened.

It is pleasant to note that the plans of Prof. Louis Agassiz-the founder of the Museum-have been, it is known, realised, and indeed beyond his most sanguine expectations, and that his son and successor now sees the establishment of a prosperous School of Natural History, amply provided with laboratories, connected with a University, and recognising in the administration of its trusts the claims of the College and of the advanced students, as well as those of the original investigator, and giving to both the latter ample opportunity of publishing their theses or researches. It has not even forgotten the specialists, for whom it has collected vast stores-stores in every way available, as most of the specialists in Europe will gladly testify.

Very truly writes Prof. A. Agassiz in reference to original investigation, that such is always best promoted in connection with educational institutions, and we would that the fact were more recognised in these co:mtries; and in regard to museums belonging to such he suggests that they should grow so fast, and no faster, as the demand for such growth arises, otherwise they become mere unwieldy and meaningless accumulations. We may add that in countries where large museums are kept up by the State, University or College Museums on an extensive scale are a vast mista':e. The college student's needs are very limited, and the money spent on adding to and keeping up collections would be infinitely better expended as aid to original research. All experienced teachers know how small is the stock of material required for their demonstrations, and how comparatively easy nowadays it is to procure such.

Prof. Agassiz hints that it would be desirable if, in connection with the Laboratory of the United States Fish Commission, the Universities of the United States should found a sea-side laboratory, which would render unnecessary, unless for special work, the various establishments already being established along the American coast. The hint should not be lost on our own Universities and Colleges, which should be urged to assist in the establishment of the British Biological Station. A long list of donations and purchases, an account of the work done, memoirs published or assisted by the loan of collections, conclude this very interesting Report.

\section{TECHNICAL EDUCATION IN NEW SOUTH WALES}

THE progress of technical education during the last few years in this country has been watched with great interest by some of our more important colonies which are desirous of not lagging too far behind the mother country in their arrangements for giving special instruction to artisans in subjects allied to the industries in which they are engaged. The Report of the Minister of Public Instruction of New South Wales recently issued contains some interesting particulars as to the establishment of a Technical College in Sydney and the organisation of trade classes in the colony. The present 